\title{
Pengaruh desentralisasi fiskal, kapasitas fiskal daerah, dan elastisitas fiskal terhadap pertumbuhan inklusif Indonesia
}

\author{
Resi Salma Nazikha, Farida Rahmawati* \\ Universitas Negeri Malang, Jl. Semarang No. 5 Malang, Jawa Timur, Indonesia \\ *Penulis korespondensi, Surel: farida.rahmawati.fe@um.ac.id
}

Paper received: 2-2-2021; revised: 20-2-2021; accepted: 27-2-2021

\begin{abstract}
Inclusive growth is defined as economic growth which not only focuses on output growth but also the impact of economic growth that occurs. The government's fiscal policy is not only directed at achieving high economic growth, but is also directed at creating an inclusive character of economic growth. The ability of regional economic independence as illustrated by fiscal decentralization, regional fiscal capacity and fiscal elasticity as a form of fiscal policy can encourage the realization of inclusive growth. This study aims to determine the effect of fiscal decentralization, regional fiscal capacity and fiscal elasticity on inclusive growth in Indonesia. This study uses multiple linear regression methods to determine the effect between variables using panel data from 34 provinces in Indonesia for 3 years (2017-2019). Data processing uses e-views software and variables are calculated using a predetermined formula. The results showed that fiscal decentralization and regional fiscal capacity had a positive and significant effect on inclusive growth, while fiscal elasticity had no significant effect on inclusive growth.
\end{abstract}

Keywords: fiscal decentralization; regional fiscal capacity; fiscal elasticity; inclusive growth

\begin{abstract}
Abstrak
Pertumbuhan inklusif diartikan sebagai pertumbuhan ekonomi yang tidak hanya fokus pada pertumbuhan output tetapi juga dampak dari pertumbuhan ekonomi yang terjadi. Kebijakan fiskal pemerintah tidak hanya diarahkan untuk mencapai pertumbuhan ekonomi yang tinggi, tetapi juga diarahkan untuk menciptakan pertumbuhan ekonomi berkarakter inklusif. Kemampuan kemandirian ekonomi daerah yang digambarkan melalui desentralisasi fiskal, kapasitas fiskal daerah dan elastisitas fiskal sebagai salah satu wujud kebijakan fiskal dapat mendorong terwujudnya pertumbuhan inklusif. Penelitian ini bertujuan untuk mengetahui pengaruh desentralisasi fiskal, kapasitas fiskal daerah dan elastisitas fiskal terhadap pertumbuhan inklusif di Indonesia. Penelitian ini menggunakan metode regresi linier berganda untuk mengetahui pengaruh antar variabel dengan menggunakan data panel 34 provinsi di Indonesia selama 3 tahun (2017-2019). Pengolahan data menggunakan software e-views dan variabel dihitung menggunakan rumus yang telah ditentukan. Hasil penelitian menunjukkan bahwa desentralisasi fiskal dan kapasitas fiskal daerah berpengaruh positif dan signifikan terhadap pertumbuhan inklusif, sedangkan elastisitas fiskal tidak berpengaruh signifikan terhadap pertumbuhan inklusif.
\end{abstract}

Kata kunci: desentralisasi fiskal; kapasitas fiskal daerah; elastisitas fiskal; pertumbuhan inklusif

\section{Pendahuluan}

Banyak negara memiliki laju pertumbuhan Produk Domestik Bruto (PDB) tinggi tapi tidak berhasil menekan tingkat kemiskinan di negaranya sedangkan ada banyak negara lain dengan laju pertumbuhan PDB yang relatif rendah dapat mengurangi jumlah orang hidup dibawah garis kemiskinan di negaranya setiap tahunnya (Tambunan, 2016). Hal tersebut tidak lain karena strategi pembangunan ekonomi yang diterapkan oleh suatu negara tidak atau kurang inklusi dalam mengintegrasikan dan mendukung pembangunan sumber daya manusia

This work is licensed under a Creative Commons Attribution-ShareAlike 4.0 International License. 
di negaranya. Sehingga, strategi pembangunan ekonomi yang diterapkan oleh suatu negara dapat lebih diarahkan pada pertumbuhan inklusif.

Pertumbuhan inklusif didefinisikan sebagai pertumbuhan ekonomi yang tidak hanya berfokus pada pertumbuhan output tetapi lebih kepada dampak yang akan ditimbulkan dari pertumbuhan ekonomi tersebut (Ramos et al., 2013). Peningkatan kesempatan kerja dan pemaksimalan partisipasi dari masyarakat untuk mendukung pertumbuhan ekonomi yang akan berdampak pada penurunan tingkat ketimpangan dan kemiskinan. Melalui konsep pertumbuhan inklusif tersebut dapat ditafsirkan pada saat pertumbuhan ekonomi naik maka kemiskinan, ketimpangan dan pengangguran akan menurun (Klasen, 2010).

Pemerintah dalam mencapai pertumbuhan ekonomi memiliki peran dalam pembuatan kebijakan yaitu kebijakan fiskal dan kebijakan moneter. Sebagai salah satu bentuk peran pemerintah, kebijakan fiskal tidak hanya diarahkan untuk mencapai pertumbuhan ekonomi yang tinggi, tetapi juga untuk menciptakan pertumbuhan ekonomi berkarakter inklusif sehingga mampu memberikan manfaat yang setara dan meningkatkan partisipasi masyarakat dalam pembangunan (Ramos et al., 2013). Selain memperhatikan kebijakan fiskal di taraf nasional, pemerintah juga harus memperhatikan kebijakan fiskal di taraf regional melalui implikasi kebijakan otonomi daerah. Setiap wilayah baik provinsi, kabupaten maupun kota merupakan pusat-pusat pertumbuhan ekonomi harus mengkapitalisasi semua potensi yang dimiliki oleh wilayahnya (Tambunan, 2016).

Desentralisasi Fiskal sebagai implementasi dari kebijakan otonomi daerah dapat menjadi ukuran kemandirian keuangan di daerah. Desentralisasi fiskal adalah pembagian kewenangan dari pemerintah pusat kepada pemerintah daerah dalam mengambil keputusan fiskal. Melalui desentralisasi fiskal dapat dilihat pembangunan ekonomi lokal sudah berjalan baik atau belum. Selain itu, kemandirian keuangan daerah juga dapat dilihat dari kapasitas fiskal daerah dan elastisitas fiskal (Aulia, 2014). Kapasitas fiskal daerah menggambarkan kondisi kemampuan keuangan di suatu daerah sedangkan elastisitas fiskal menggambarkan struktur Pendapatan Asli Daerah di suatu daerah. Ketiga hal tersebut merupakan implikasi dari kebijakan otonomi daerah dan kemandirian daerah dalam mengembangkan pembangunan ekonomi lokal.

Penguatan kembali hubungan antar wilayah menjadi penting dalam hal mencapai pertumbuhan yang inklusif agar hasil dari ekonomi dapat dirasakan oleh semua pihak. Melalui kebijakan otonomi daerah, pemerintah daerah akan lebih tanggap terhadap kebutuhan masyarakat karena cakupannya yang lebih sempit maka hal tersebut cenderung lebih efektif dan efisien (Murad, 2019). Sehingga dengan tercapainya kemandirian daerah yang tercermin melalui desentralisasi fiskal, kapasitas fiskal daerah dan elastisitas fiskal dapat mendorong terwujudnya pertumbuhan ekonomi yang inklusif.

Penelitian yang dilakukan oleh Ahmad Murad (2019) tentang desentralisasi fiskal terhadap inklusivitas pertumbuhan ekonomi kabupaten/kota di NTB menggunakan variabel Pendapatan Asli Daerah dalam menggambarkan kondisi desentralisasi fiskal dan pertumbuhan ekonomi inklusif melalui pendekatan klasen yang meliputi penurunan kemiskinan, penurunan ketimpangan ekonomi dan penyerapan tenaga kerja. Kemudian, penelitian yang dilakukan oleh Nely Aulia (2014) menggunakan variabel terikat berupa pertumbuhan ekonomi, tingkat kemiskinan, dan kesenjangan pendapatan serta variabel bebas berupa desentralisasi fiskal, elastisitas PAD dan kapasitas fiskal. 


\subsection{Pertumbuhan Inklusif}

Menurut Prasetyantoko, dkk 2012 dalam (Tambunan, 2016), pembangunan ekonomi inklusif adalah pembangunan yang dilakukan untuk semua orang tidak peduli latar belakang dan perbedaannya. Pertumbuhan inklusif tidak hanya ditujukan untuk menciptakan peluang ekonomi baru, tetapi juga akan memastikan kesempatan yang sama untuk semua masyarakat khususnya masyarakat miskin. Pertumbuhan dikatakan inklusif apabila dapat meningkatkan fungsi kesempatan sosial yang bergantung pada 2 (dua) faktor yaitu peluang rata-rata yang tersedia bagi masyarakat dan bagaimana peluang dibagi kepada masyarakat (Sitorus \& Arsani, 2018).

Menurut International Policy Centre for Inclusive Growth UNDP pertumbuhan inklusif melibatkan outcome dan proses serta partisipasi dan benefit-sharing sehingga memberikan kesempatan kepada setiap orang untuk berpartisipasi dalam proses pertumbuhan dan memastikan manfaatnya terdistribusikan dengan baik kepada seluruh masyarakat. (Ramos et al., 2013) membagi Indeks inklusif menjadi tiga indikator yaitu: kemiskinan, ketimpangan, dan rasio tenaga kerja terhadap populasi. Selain itu, konsep Pertumbuhan Ekonomi Inklusif dalam strategi ADB 2020 menekankan pada pertumbuhan ekonomi dengan kesetaraan kesempatan yang terdiri dari 3 dimensi yaitu a) Pertumbuhan yang tinggi dan berkelanjutan akan menciptakan peluang ekonomi, b) Social inclusion untuk memastikan setiap anggota masyarakat berkesempatan yang sama atas peluang ekonomi, c) Social safety nets untuk melindungi masyarakat miskin dan rentan (Zhuang, 2010).

World Economic Forum atau WEF menyusun Inclusive Growth and Development Index (IDI) berdasarkan 7 pilar yaitu education and skills, basic services and infrastructure, employment and labor compensation, corruption and rents, financial intermediation of real economy investment, asset building and entrepreneurship, dan fiscal transfers. IDI disusun dengan menggunakan data tahun 2016 dengan 109 negara dan hasilnya dikelompokkan menjadi negara berpendapatan rendah, negara berpendapatan menengah ke bawah, negara berpendapatan menengah ke atas dan negara ekonomi maju berdasarkan PDB per kapita (Sitorus \& Arsani, 2018).

Indeks Pembangunan Ekonomi Inklusif yang disusun oleh Indonesia merupakan alat untuk mengukur dan memantau sejauh mana tingkat inklusivitas pembangunan Indonesia baik pada level nasional, provinsi dan kabupaten/kota. Indeks Pembangunan Ekonomi Inklusif mengukur tingkat inklusivitas pembangunan ekonomi di Indonesia melalui aspek pertumbuhan ekonomi, kemiskinan dan ketimpangan, serta akses dan kesempatan.

\subsection{Desentralisasi Fiskal}

Menurut Undang-Undang Nomor 33 Tahun 2004 tentang Perimbangan Keuangan antara Pemerintah Pusat dan Pemerintahan Daerah Pasal 1 ayat 8, "Desentralisasi adalah penyerahan wewenang pemerintahan oleh Pemerintah kepada daerah otonom untuk mengatur dan mengurus urusan pemerintahan dalam sistem Negara Kesatuan Republik Indonesia." Desentralisasi fiskal adalah proses pendelegasian wewenang (anggaran) dari tingkat pemerintahan yang lebih tinggi kepada pemerintahan yang lebih rendah dalam rangka mendukung fungsi atau tugas pemerintahan dan pelayanan publik sesuai dengan banyaknya kewenangan bidang pemerintahan yang dilimpahkan (Aulia, 2014). 
Desentralisasi fiskal merupakan wujud pelaksanaan otonomi daerah dalam aspek pengelolaan keuangan daerah (Hastuti, 2018). Pelimpahan kewenangan diberikan untuk semua bidang kecuali kewenangan dalam bidang politik luar negeri, pertahanan, keamanan, yustisi, moneter dan fiskal, serta keagamaan. Pelimpahan kewenangan tersebut juga diikuti dengan adanya penyerahan sumber pendanaan dari basis perpajakan dan bantuan pendanaan melalui mekanisme transfer ke daerah sesuai dengan asas money follows function.Dalam melaksanakan desentralisasi fiskal, prinsip money follow function memiliki arti setiap penyerahan atau pelimpahan wewenang pemerintahan akan membawa konsekuensi pada anggaran yang diperlukan dalam pelaksanaan kewenangan tersebut. Desentralisasi fiskal diperlukan untuk perbaikan efisiensi ekonomi, perbaikan akuntabilitas peningkatan mobilisasi dana, dan efisiensi biaya. Pelaksanaan desentralisasi fiskal juga harus disesuaikan dengan latar belakang sejarah dan kebudayaan, kondisi-kondisi lembaga, politik, dan ekonomi di masing-masing daerah.

Desentralisasi fiskal mencakup beberapa hal yaitu: (1) Adanya staff financing atau cost recovery dalam pelayanan publik terutama pengenaan retribusi daerah, (2) Pengguna jasa publik berpartisipasi dalam bentuk pembayaran jasa atau kontribusi tenaga kerja (Cofinancing atau coproduction), (3) Peningkatan PAD melalui penambahan kewenangan pengenaan pajak daerah terutama pajak properti (PBB), pajak penghasilan perseroan (PPh pribadi), cukai atas berbagai komoditas atau berbagai jenis retribusi daerah, (4) Transfer pemerintah pusat terutama yang berasal dari DAU, DAK, sumbangan darurat dan bagi hasil pajak dan bukan pajak, serta (5) Kebebasan daerah untuk melakukan pinjaman (Murad, 2019).

Menurut Oates (1993) desentralisasi fiskal telah menjadi sebuah rujukan penting untuk menjadikan pertumbuhan ekonomi di daerah menjadi lebih baik dan efisien. Dengan berpindahnya beberapa kewenangan dan pengelolaan keuangan dari pemerintah pusat ke pemerintah daerah diharapkan kebijakan publik yang telah dibuat menjadi lebih efektif dan efisien. Selain itu pelayanan dan penyediaan kebutuhan publik akan sesuai dengan kebutuhan masyarakat dan pemerintah daerah. Sehingga, dengan adanya pemberian wewenang dapat meningkatkan kemampuan daerah dalam melayani kebutuhan barang publik dengan lebih baik dan efisien (Hidayat, 2017).

\subsection{Kapasitas Fiskal Daerah}

Kapasitas Fiskal Daerah menggambarkan kondisi kemampuan keuangan di suatu daerah. Peraturan Menteri Keuangan No. 126/PMK.07/2019 tentang Peta Kapasitas Fiskal Daerah menerangkan bahwa Kapasitas Fiskal Daerah (KFD) adalah kemampuan keuangan masing-masing daerah yang dicerminkan melalui pendapatan daerah dikurangi dengan pendapatan yang penggunaanya sudah ditentukan dan belanja tertentu. Kapasitas fiskal menunjukkan kemampuan daerah dalam membiayai sendiri kegiatan pembangunan, pemerintahan, dan pelayanan kepada masyarakat yang telah membayar pajak dan retribusi sebagai sumber pendapatan yang diperlukan daerah.

Dalam praktek dan implementasinya terdapat beberapa penggunaan data Kapasitas Fiskal Daerah yang dihitung melalui pendekatan yang berbeda-beda (Herdiyana, 2019). Terdapat 5 (lima) pendekatan yang digunakan dalam menghitung Kapasitas Fiskal Daerah yaitu: (1) Kapasitas Fiskal yang menjadi dasar pengalokasian DAU yaitu sebagaimana diamanatkan pada Pasal 27 Ayat (3) dan Pasal 28 Ayat (3) Undang-Undang Nomor 33 Tahun 
2004 dan PP Nomor 55 Tahun 2005 tentang Dana Perimbangan. Dana Alokasi Umum adalah dana yang bersumber dari pendapatan APBN yang dialokasikan dengan tujuan pemerataan kemampuan keuangan antar-daerah untuk mendanai kebutuhan daerah dalam rangka pelaksanaan Desentralisasi Fiskal. (2) Kemampuan Keuangan Daerah untuk perhitungan Dana Alokasi Khusus dimuat dalam Pasal 40 Ayat (2) UU Nomor 33 Tahun 2004 dan Penjelasannya. Ketentuan tersebut ditegaskan dalam PP Nomor 55 Tahun 2005 tentang Dana Perimbangan. (3) Kemampuan Fiskal Daerah yang digunakan dalam perencanaan pendanaan urusan bersama untuk penanggulangan kemiskinan sebagaimana diatur pada Peraturan Presiden Nomor 13 Tahun 2009 tentang Koordinasi Penanggulangan Kemiskinan yang telah disempurnakan menjadi Perpres Nomor 15 Tahun 2010 tentang Percepatan Penanggulangan Kemiskinan. Adapun di tahun 2012 telah ditetapkan dengan PMK Nomor 66/PMK.07/2011 tentang Indeks Fiskal dan Kemiskinan Daerah Dalam Rangka Perencanaan Pendanaan Urusan Bersama untuk Penanggulangan Kemiskinan Tahun 2012. (4) Kemampuan Keuangan Daerah yang ditetapkan Menteri Dalam Negeri sebagai dasar penghitungan tunjangan keuangan anggota DPRD.

\subsection{Elastisitas Fiskal}

Tingkat ekonomi dapat diukur melalui indikator ekonomi berupa pertumbuhan PDRB dan sektor-sektor kegiatan ekonomi yang memberikan sumbangan relatif besar terhadap PDRB tersebut. PDRB perkapita mencerminkan seluruh kegiatan ekonomi yang ada di suatu daerah. Oleh karena itu, semakin besar PDRB suatu daerah maka semakin besar pula Pendapatan Asli Daerah yang diperoleh daerah tersebut. Pendapatan Asli Daerah digunakan untuk mendanai pelaksanaan otonomi daerah. Dalam melaksanakan otonomi daerah tersebut harus disesuaikan dengan potensi ekonomi di daerah, agar tujuan dari pembangunan dapat tercapai secara maksimal.

Pendapatan Asli Daerah digunakan sebagai salah satu komponen dalam menghitung Elastisitas Fiskal. Konsep elastisitas fiskal erta dikaitkan dengan konsep fleksibilitas sistem fiskal. Koefisien elastisitas didasarkan pada berubah tidaknya struktur fiskal yang dianalisis. Perubahan pada penerimaan pajak hanya dipengaruhi oleh perubahan PDRB. Apabila struktur fiskal berubah maka koefisien elastisitas dapat menjadi mendukung penerimaan pajak (buoyancy of tax). Hal ini menunjukkan bahwa koefisien elastisitas akan dipengaruhi oleh perubahan PAD (pajak) dan perubahan PDRB.

\subsection{Hubungan Variabel Desentralisasi Fiskal terhadap Pertumbuhan Inklusif}

Kebijakan otonomi daerah dan desentralisasi fiskal pada umumnya bertujuan mendorong pertumbuhan ekonomi di daerah. Pemberian wewenang yang lebih luas diharapkan mampu mengoptimalkan potensi ekonomi yang ada di daerah. Dengan adanya desentralisasi fiskal tersebut akan memberikan efek positif terhadap pertumbuhan ekonomi yang dapat dilihat dari rata-rata pertumbuhan perkapita. Selain itu, besarnya transfer dana di daerah juga dapat memiliki hubungan positif terhadap peningkatan kesejahteraan masyarakat. Desentralisasi fiskal dapat mendorong pendapatan perkapita di daerah sehingga dapat mengurangi penduduk miskin (Zulyanto, 2012).

Pembangunan di daerah-daerah yang bersifat pembangunan regional maupun pembangunan wilayah atas pembangunan kawasan dalam skala apapun merupakan bagian 
terpadu dari pembangunan nasional yang ditujukan untuk meningkatkan kemampuan dan kesejahteraan masyarakat secara merata (Dyah Hapsari et al., 2018). Penyerahan wewenang dari pemerintah pusat kepada daerah melalui desentralisasi fiskal diharapkan dapat meningkatkan pelayanan yang lebih efektif dan efisien kepada masyarakat yang pada akhirnya akan mendorong terciptanya pertumbuhan ekonomi daerah dan kesejahteraan masyarakat lokal. Dengan kata lain desentralisasi fiskal dapat membantu terwujudnya pertumbuhan inklusif melalui penyediaan barang publik untuk kemudahan akses bagi seluruh masyarakat yang disertai dengan adanya pertumbuhan ekonomi di daerah.

\subsection{Hubungan Variabel Kapasitas Fiskal Daerah terhadap Pertumbuhan Inklusif}

Kapasitas fiskal daerah adalah alat yang digunakan untuk melihat kemampuan keuangan daerah. Komponen penting dalam perhitungan kapasitas fiskal daerah adalah komponen dana perimbangan yaitu dana alokasi umum dan dana alokasi khusus. Alokasi dana perimbangan yang diberikan dimaksudkan untuk mengurangi ketimpangan vertikal antara pemerintah pusat dan pemerintah daerah, serta bertujuan untuk mengurangi kesenjangan horizontal antar pemerintah daerah (Herdiyana, 2019). Selain itu, daerah juga diberikan kewenangan untuk memungut pajak/retribusi daerah sehingga diharapkan daerah mampu menyediakan pelayanan kepada masyarakat dengan standar pelayanan minimal.

Todaro, (2000) mengemukakan konsep bahwa kapasitas fiskal memiliki pengaruh yang signifikan terhadap pertumbuhan ekonomi. Dimana pada saat kapasitas fiskal meningkat maka pertumbuhan ekonomi juga meningkat. Sehingga, dapat dikatakan bahwa kapasitas fiskal daerah berpengaruh terhadap pertumbuhan ekonomi inklusif melalui indikator pertumbuhan ekonomi, pengurangan ketimpangan dan kemudahan akses bagi masyarakat.

\subsection{Hubungan Variabel Elastisitas Fiskal terhadap Pertumbuhan Inklusif}

Elastisitas Fiskal menggambarkan kondisi pajak di suatu daerah. Semakin elastis nilai dari pendapatan asli daerah maka semakin kuat pula struktur pajak di daerah tersebut. Struktur pajak yang kuat akan menjadikan suatu daerah tersebut menjadi daerah yang mandiri dari sisi keuangan daerah. Daerah tersebut mampu memenuhi kebutuhan masyarakat baik dalam hal infrastruktur maupun dalam hal pembangunan sumber daya manusia. Sehingga, elastisitas fiskal dikatakan dapat mempengaruhi pertumbuhan ekonomi inklusif melalui indikator infrastruktur dan kemudahan akses masyarakat.

\section{Metode}

Penelitian ini dilakukan menggunakan metode analisis deskriptif dengan pendekatan kuantitatif. Metode analisis deskriptif digunakan untuk menjelaskan gambaran umum perkembangan setiap variabel yang digunakan. Pendekatan kuantitatif yang digunakan dalam menganalisis penelitian ini adalah menggunakan analisis regresi linier berganda menggunakan data panel 34 provinsi di Indonesia selama 3 tahun yaitu 2017-2019. Variabel yang digunakan adalah variabel desentralisasi fiskal, variabel kapasitas fiskal daerah dan variabel elastisitas fiskal sebagai variabel bebas serta variabel pertumbuhan inklusif sebagai variabel terikat.

Sebelum melakukan olah data regresi, setiap variabel yang digunakan akan dihitung terlebih dahulu sesuai dengan rumus perhitungan yang telah ditentukan. Variabel desentralisasi fiskal diperoleh dari perhitungan rumus derajat desentralisasi fiskal. Rumus derajat desentralisasi fiskal adalah sebagai berikut: 


$$
D F_{i t}=\frac{P A D_{i t}}{T P D_{i t}} \times 100
$$

Variabel kapasitas fiskal daerah diperoleh dari perhitungan rumus indeks kapasitas fiskal daerah dengan rumus sebagai berikut:

$$
I K F D_{\text {provinsi }-i}=\frac{K F D_{\text {provinsi-i }}}{\left(\sum K F D_{\text {provinsi }-i}\right) / n}
$$

Variabel elastisitas fiskal diperoleh dari perhitungan rumus elastisitas fiskal sebagai berikut:

$$
e_{i t}=\frac{\Delta P A D_{i t}}{\triangle P D R B_{i t}} x \frac{P D R B_{i t}}{P A D_{i t}}
$$

Variabel pertumbuhan inklusif digambarkan dalam Indeks Pembangunan Ekonomi Inklusif yang dipublikasikan oleh Badan Perencanaan Pembangunan Nasional.

Model persamaan regresi dalam penelitian yang digunakan adalah sebagai berikut:

$$
Y=\beta_{0}+\beta_{1} X_{1}+\beta_{2} X_{2}+\beta_{3} X_{3}+\varepsilon
$$

Keterangan:

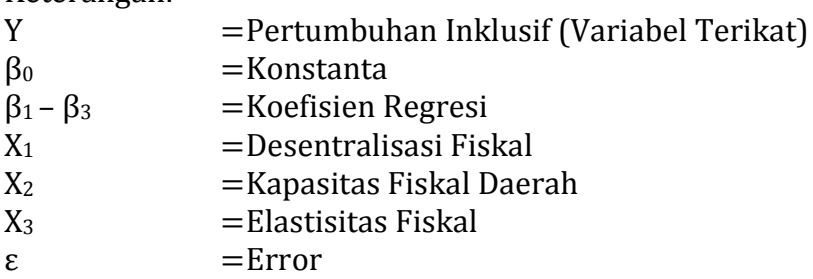

Penelitian yang menggunakan data panel diperlukan adanya pemilihan metode estimasi model regresi yang dilakukan melalui tiga pendekatan yaitu Commont Effects Model, Fixed Effects Model, dan Random Effects Model. Setelah metode estimasi dipilih kemudian akan dilakukan pemilihan model regresi panel melalui 3 pengujian model yaitu Uji Chow (untuk menentukan model Fixed Effects atau Common Effects dalam mengestimasi data panel), Uji Hausman (untuk memilih apakah model Fixed Effects atau Random Effects dalam mengestimasi data panel), dan Uji Lagrange Multiplier (untuk mengetahui apakah model Random Effects lebih baik daripada metode Commont Effects) (Basuki \& Nano Prawoto, 2016)

Selain itu, model penelitian yang dibuat harus memenuhi standar statistik sehingga diperlukan adanya uji hipotesis dan harus memenuhi asumsi-asumsi penelitian sehingga diperlukan adanya uji asumsi klasik. Uji hipotesis yang digunakan terdiri dari 3 (tiga) uji yaitu Uji T (untuk mengetahui signifikansi variabel bebas dalam menjelaskan variabel terikat secara individual) dilakukan dengan melihat nilai t-hitung > nilai t-tabel, Uji F (untuk mengetahui signifikansi variabel bebas dalam menjelaskan variabel terikat secara simultan) dilakukan dengan melihat nilai f-hitung > f-tabel, dan Uji $\mathrm{R}^{2}$ (untuk melihat kemampuan variabel bebas dalam menjelaskan variabel terikat) dilihat dari nilai R-Square. Uji asumsi klasik yang digunakan dalam penelitian ini terdiri dari 2 uji yaitu Uji Multikolinieritas (untuk menguji korelasi antar variabel bebas) dilakukan dengan melihat nilai Variance Inflation Factors (VIF) yang harus lebih besar dari 10 (VIF > 10), dan Uji Heterokedastisitas (untuk menguji varian 
error konstan atau tidak) melalui uji Glejser dengan melihat nilai probabilitas setiap variabel lebih dari alpha (Gujarati \& Porter, 2013).

\section{Hasil dan Pembahasan}

\subsection{Hasil Penelitian}

Pertumbuhan inklusif Indonesia selama tahun 2017-2019 berturut-turut adalah sebesar 5.75, 5.75, dan 5.89. Setiap provinsi di Indonesia memiliki nilai pertumbuhan inklusif yang beragam. Provinsi yang memiliki pertumbuhan inklusif tertinggi adalah Provinsi DKI Jakarta dengan rata-rata sebesar 7.61 dan Provinsi Bali dengan rata-rata sebesar 6.63. Sedangkan Provinsi Papua menjadi satu-satunya provinsi di Indonesia yang masih masuk dalam kategori pertumbuhan inklusif tidak memuaskan dengan rata-rata sebesar 3.44 (berada dibawah 4).

Desentralisasi fiskal yang terjadi di setiap provinsi di Indonesia memiliki nilai yang beragam. Sebagian besar desentralisasi fiskal yang tinggi terletak pada wilayah yang berada di Pulau Jawa. Provinsi DKI Jakarta dan Provinsi Banten serta Provinsi Bali menjadi provinsi yang memiliki desentralisasi fiskal tertinggi dengan rata-rata selama tiga tahun yaitu sebesar 0.71 , 0.61 , dan 0.59. Sedangkan provinsi yang memiliki desentralisasi fiskal terkecil berada di wilayah Papua yaitu Provinsi Papua Barat dan Provinsi Papua dengan rata-rata masing-masing provinsi sebesar 0.06 dan 0.10 .

Kapasitas fiskal daerah di Indonesia berada pada rentang sangat rendah, rendah dan tinggi, sampai pada tahun 2019 terlihat bahwa belum ada provinsi yang sampai pada level sangat tinggi. Terdapat 13 provinsi yang memiliki rata-rata kapasitas fiskal tergolong sangat rendah yaitu Provinsi Kalimantan Barat sebesar 0.48, Provinsi Sulawesi Utara sebesar 0.45, Provinsi Nusa Tenggara Barat sebesar 0.44, Provinsi Jambi sebesar 0.42, Provinsi Nusa Tenggara Timur sebesar 0.35, Provinsi Bengkulu dan Provinsi Sulawesi Tengah 0.34, Provinsi Sulawesi Tenggara 0.32, Provinsi Maluku 0.31, Provinsi Maluku Utara sebesar 0.28, Provinsi Sulawesi Barat 0.23, Provinsi Gorontalo sebesar 0.21 dan Provinsi Papua sebesar 0.18. Sedangkan provinsi yang memiliki rata-rata kapasitas fiskal daerah tertinggi adalah Provinsi DKI Jakarta sebesar 0.99 dan masuk dalam kategori sedang.

Tidak semua provinsi di Indonesia memiliki nilai elastis untuk keadaan fiskal di daerahnya. Terdapat 11 (sebelas) provinsi yang memiliki nilai fiskal bersifat inelastis yaitu Provinsi Riau, Provinsi Jambi, Provinsi Sumatera Selatan, Provinsi Bengkulu, Provinsi Bangka Belitung, Provinsi DKI Jakarta, Provinsi Kalimantan Selatan, Provinsi Kalimantan Utara, Provinsi Maluku, Provinsi Papua Barat dan Provinsi Papua. Inelastisitas dalam perhitungan ini memiliki arti bahwa setiap ada perubahan pada nilai PDRB tidak begitu berpengaruh terhadap PAD yang diperoleh di daerahnya.

\subsubsection{Analisis Data}

\subsubsection{Uji Signifikansi Parsial (Uji T)}

Uji $\mathrm{T}$ dalam penelitian dilakukan untuk mengetahui pengaruh dari masing-masing variabel independen dengan variabel dependen. 
Tabel 1. Hasil Uji T

\begin{tabular}{llll}
\hline Variabel & t-hitung & t-tabel & Kesimpulan \\
\hline Desentralisasi Fiskal & 5.77 & 1.960 & Signifikan \\
Kapasitas Fiskal Daerah & 2.76 & 1.960 & Signifikan \\
Elastisitas Fiskal & 0.11 & 1.960 & Tidak Signifikan \\
\hline
\end{tabular}

Sumber: Data diolah, 2020

H0: Desentralisasi Fiskal, Kapasitas Fiskal Daerah dan Elastisitas Fiskal tidak mempengaruhi Pertumbuhan Inklusif secara signifikan.

H1: Desentralisasi Fiskal, Kapasitas Fiskal Daerah dan Elastisitas Fiskal mempengaruhi Pertumbuhan Inklusif secara signifikan.

Berdasarkan hasil pengolahan data di tabel 4.1 maka dapat diambil kesimpulan bahwa: (1) Terdapat pengaruh positif dan signifikan antara variabel desentralisasi fiskal terhadap pertumbuhan inklusif sehingga $\mathrm{H}_{0}$ diterima dan $\mathrm{H}_{1}$ ditolak. Hal ini terjadi karena jumlah $\mathrm{t}$ hitung yaitu 5.77 lebih besar dari t-tabel yaitu 1.960. (2) Terdapat pengaruh positif dan signifikan antara variabel kapasitas fiskal daerah terhadap pertumbuhan inklusif sehingga $\mathrm{H}_{0}$ diterima dan $\mathrm{H}_{1}$ ditolak. Hal ini terjadi karena jumlah t-hitung yaitu 2.76 lebih besar dari t-tabel yaitu 1.960. (3) Terdapat pengaruh positif dan tidak signifikan antara variabel elastisitas fiskal terhadap pertumbuhan inklusif sehingga $\mathrm{H}_{1}$ diterima dan $\mathrm{H}_{0}$ ditolak. Hal ini terjadi karena jumlah t-hitung yaitu 0.11 lebih kecil dari t-tabel yaitu 1.960 .

\subsubsection{Uji Signifikansi Simultan (Uji F)}

Uji F dilakukan untuk mengetahui pengaruh variabel dependen secara simultan atau bersama-sama terhadap variabel dependen.

Tabel 2. Hasil Uji F

\begin{tabular}{ll}
\hline F-hitung & F-tabel \\
\hline 17.46 & 5.80 \\
\hline
\end{tabular}

Sumber: Data diolah, 2020

Berdasarkan hasil uji diatas, dapat dilihat bahwa nilai F-hitung > F-tabel dimana 17.46 > 5.80. Pada Uji F, p-value (alpha $=5 \%$ maka tolak $\mathrm{H}_{0}$ pada tingkat signifikansi $=5 \%$, artinya pada tingkat signifikansi 5\% variabel independen yaitu desentralisasi fiskal, kapasitas fiskal daerah, dan elastisitas fiskal secara bersama-sama memberikan pengaruh signifikan terhadap variabel dependen yaitu pertumbuhan inklusif.

\subsubsection{Koefisien Determinasi $\left(R^{2}\right)$}

Dari hasil estimasi, besarnya $\mathrm{R}^{2}$ yang diperoleh untuk tingkat pertumbuhan inklusif adalah sebesar 0.348249. Artinya variabel independen desentralisasi fiskal, kapasitas fiskal daerah, dan elastisitas fiskal mampu menjelaskan variabel dependen pertumbuhan inklusif sebesar $34.82 \%$. Sementara $65.18 \%$ sisanya dijelaskan oleh variabel-variabel lain yang tidak terdapat dalam model ini dan faktor-faktor lainnya. Dari nilai koefisien determinasi tersebut maka dapat dideskripsikan bahwa variabel independen signifikan mempengaruhi variabel 
dependen dalam analisis ini. Sehingga dapat disimpulkan model ini cukup baik dan dapat menjelaskan permasalahan dari penelitian ini.

\subsubsection{Asumsi Klasik Uji Multikolinearitas}

Uji Multikolinearitas digunakan untuk mengetahui ada atau tidaknya korelasi antara variabel bebas yang digunakan.

Tabel 3. Hasil Uji Multikolinearitas

\begin{tabular}{lll}
\hline Variabel & VIF & Coefficient Variance \\
\hline Desentralisasi Fiskal & 1.692190 & 0.130324 \\
Kapasitas Fiskal Daerah & 1.673606 & 0.059999 \\
Elastisitas Fiskal & 1.021301 & 0.001837 \\
\hline Sumber: Data diolah, 2020 & &
\end{tabular}

Berdasarkan pengolahan data yang telah dilakukan, terlihat bahwa nilai VIF setiap variabel berada dibawah 10 (desentralisasi fiskal 1.69, kapasitas fiskal daerah 1.67 dan elastisitas fiskal 1.02) sehingga model yang digunakan dalam penelitian ini memenuhi asumsi karena tidak memiliki gejala multikolinearitas.

\subsubsection{Asumsi Klasik Uji Heterokedastisitas} tidak.

Uji Heterokedastisitas digunakan untuk mengetahui varian error apakah konstan atau

Tabel 4. Uji Heterokedastisitas

\begin{tabular}{ll}
\hline Variabel & Prob. \\
\hline Desentralisasi Fiskal & 0.5499 \\
Kapasitas Fiskal Daerah & 0.6416 \\
Elastisitas Fiskal & 0.1062 \\
\hline
\end{tabular}

Sumber: Data diolah, 2020

Dalam pengujian ini menggunakan tes Glejser dan menghasilkan nilai probabilitas masing-masing variabel melebihi alpha 0.05 (desentralisasi fiskal 0.5499, kapasitas fiskal daerah 0.6416 dan elastisitas fiskal 1.1062) sehingga dapat disimpulkan bahwa model yang digunakan dalam penelitian memenuhi asumsi karena tidak memiliki gejala heterokedastisitas.

\subsection{Pembahasan}

\subsubsection{Pengaruh Desentralisasi Fiskal terhadap Pertumbuhan Inklusif}

Berdasarkan hasil analisis data yang telah dilakukan oleh peneliti diperoleh hasil bahwa derajat desentralisasi fiskal berpengaruh positif dan signifikan terhadap pertumbuhan inklusif di 34 provinsi selama tahun 2017-2019. Koefisien variabel desentralisasi fiskal sebesar 2.653252 dengan probabilitas 0.0000 menjelaskan bahwa setiap adanya peningkatan satusatuan desenstralisasi fiskal maka dapat meningkatkan pertumbuhan inklusif sebesar 2.653252 poin. Hal ini dapat diartikan bahwa apabila derajat desentralisasi fiskal mengalami 
peningkatan maka pertumbuhan inklusif juga akan mengalami peningkatan karena memiliki pengaruh yang positif. Sehingga semakin tinggi derajat desentralisasi fiskal maka pertumbuhan inklusif akan semakin tinggi pula.

Pendapatan Asli Daerah digunakan dalam menghitung desentralisasi fiskal yang akan menggambarkan penerimaan daerah yang sesungguhnya. Sehingga dapat dilihat sejauh mana desentralisasi fiskal terjadi di daerah tersebut. Hasil perhitungan menunjukkan bahwa ratarata desentralisasi fiskal di Indonesia berada di angka 0.36 yang menunjukkan bahwa desentralisasi fiskal di Indonesia sudah baik dari sisi penerimaan. Terdapat satu provinsi yang memiliki nilai desentralisasi dibawah 0.1 yaitu Provinsi Papua dengan nilai desentralisasi fiskal sebesar 0.04 .

Realisasi Anggaran Pendapatan dan Belanja Daerah (RAPBD) pada pos penerimaan dari 34 Provinsi di Indonesia menunjukkan bahwa sebagian besar sumbangan terbesar adalah dari Dana Perimbangan yang berasal dari pemerintah pusat. Terdapat 5 Provinsi yang memiliki pos Pendapatan Asli Daerah terbesar dibandingkan dengan pos penerimaan lainnya yaitu Provinsi DKI Jakarta, Provinsi Jawa Tengah, Provinsi Kalimantan Selatan, Provinsi Kalimantan Timur, dan Provinsi Bali. Kemudian ada 2 Provinsi yang memiliki sumbangan penerimaan terbesar berasal dari Lain-Lain Pendapatan Daerah yang Sah yaitu Provinsi Aceh dan Provinsi Papua. Dengan adanya pos Dana Perimbangan tersebut dapat dimanfaatkan dengan sebaiknya oleh daerah untuk membangun daerahnya terutama dalam hal pemenuhan pelayanan publik untuk kesejahteraan masyarakat.

Hal ini mendukung teori Oates dimana berpindahnya beberapa kewenangan dan pengelolaan keuangan dari pemerintah pusat ke pemerintah daerah akan menjadikan kebijakan yang dibuat menjadi lebih efektif dan efisien serta pelayanan dan penyediaan kebutuhan publik menjadi selaras dengan kebutuhan masyarakat dan pemerintah daerah. Sehingga, desentralisasi fiskal yang baik akan mendorong terjadinya pertumbuhan inklusif di Indonesia.

Hasil penelitian ini sesuai dengan hasil penelitian Ahmad Murad (2019) yang memberikan hasil bahwa pelaksanaan otonomi daerah melalui desentralisasi fiskal mempunyai kemampuan dalam hal mendorong kenaikan kesejahteraan masyarakat dan dalam hal mengurangi ketimpangan serta pengangguran dan kemiskinan sebagai bagian dari indikator dalam pembangunan inklusif di Indonesia. Hal tersebut disebabkan pemberian transfer dari pemerintah pusat dalam bentuk dana perimbangan kepada daerah di Nusa Tenggara Barat dapat dimanfaatkan oleh pemerintah daerah untuk meningkatkan kualitas hidup masyarakatnya. Hal ini sejalan pula dengan penelitian yang dilakukan oleh Nelly Aulia (2014) yang memberikan hasil bahwa derajat desentralisasi fiskal memiliki hubungan yang erat dengan pertumbuhan ekonomi, tingkat kemiskinan dan kesenjangan pendapatan.

Penelitian dari Fatih Sabilul Islam (2015) memberikan kesimpulan bahwa desentralisasi fiskal berpengaruh signifikan terhadap pertumbuhan ekonomi, kemiskinan, pengangguran dan ketimpangan pendapatan di Kabupaten/Kota di Jawa Tengah dimana penelitian tersebut menekankan bahwa desentralisasi fiskal yang terjadi mendukung teori dari Oates yaitu desentralisasi fiskal yang terjadi mampu meningkatkan pertumbuhan ekonomi dan kesejahteraan masyarakat. Namun hasil penelitian ini bertolak belakang dengan penelitian yang dilakukan oleh Dwi Esti Kurniasih (2020) yang memberikan kesimpulan bahwa desentralisasi fiskal tidak memiliki efek yang moderat terhadap infrastruktur dan 
pertumbuhan ekonomi inklusif dan adanya desentralisasi fiskal saat ini masih belum bisa mempererat hubungan antara infrastruktur terhadap pertumbuhan ekonomi yang inklusif di Indonesia.

\subsubsection{Pengaruh Kapasitas Fiskal Daerah terhadap Pertumbuhan Inklusif}

Berdasarkan hasil analisis data yang telah dilakukan oleh peneliti diperoleh hasil bahwa kapasitas fiskal daerah berpengaruh positif dan signifikan terhadap pertumbuhan inklusif di 34 provinsi yang ada di Indonesia tahun 2017-2019. Koefisien variabel kapasitas fiskal daerah sebesar 0.375605 dengan probabilitas 0.0070 menjelaskan bahwa setiap adanya peningkatan satu-satuan kapasitas fiskal daerah maka dapat meningkatkan pertumbuhan inklusif sebesar 0.375605 poin. Hal ini dapat diartikan bahwa apabila kapasitas fiskal daerah mengalami peningkatan maka pertumbuhan inklusif juga akan mengalami peningkatan karena memiliki pengaruh yang positif. Sehingga semakin tinggi kapasitas fiskal daerah maka pertumbuhan inklusif akan semakin tinggi pula.

Kapasitas fiskal daerah menghitung pendapatan yang sudah dikurangi oleh pendapatan yang penggunaannya sudah ditentukan dan belanja tertentu. Perhitungan Indeks Kapasitas Fiskal Daerah berguna sebagai pertimbangan dalam menetapkan daerah penerima hibah, penentuan besaran dana pendampingan oleh pemerintah daerah dan penggunaan lain sesuai dengan ketentuan peraturan perundang-undangan. Hal tersebut tentu akan berpengaruh bagi pertumbuhan ekonomi di daerah tersebut. Pemerintah daerah mendayagunakan sumber daya dan potensi daerah untuk tujuan pembangunan daerah melalui pengelolaan APBD yang efektif dan produktif dengan mengurangi belanja konsumtif, meningkatkan PAD dan memperbesar alokasi belanja modal. Hal itu bertujuan untuk mendorong percepatan pembangunan daerah dan peningkatan kesejahteraan masyarakat. Hal ini sejalan dengan konsep yang dikemukakan oleh Todaro (2000) yang menyatakan bahwa kapasitas fiskal memiliki pengaruh yang signifikan terhadap pertumbuhan ekonomi. Kapasitas fiskal yang tinggi dapat meningkatkan pertumbuhan ekonomi.

Penelitian ini juga sejalan dengan penelitian yang dilakukan oleh Nely Aulia (2014) yang memberikan hasil bahwa kapasitas fiskal, derajat desentralisasi fiskal dan elastisitas fiskal berpengaruh signifikan terhadap pertumbuhan ekonomi, tingkat kemiskinan, dan kesenjangan pendapatan. Namun, penelitian ini bertolak belakang dengan penelitian yang dilakukan oleh Juma'eh, dkk (2020) memberikan hasil bahwa kapasitas fiskal memiliki pengaruh negatif terhadap pertumbuhan ekonomi, dimana semakin tinggi kapasitas fiskal yang terjadi di suatu daerah akan menurunkan pertumbuhan ekonomi di daerah tersebut dan kapasitas fiskal tidak memiliki pengaruh terhadap kesejahteraan masyarakat yang diukur melalui Indeks Pembangunan Manusia.

\subsubsection{Pengaruh Elastisitas Fiskal terhadap Pertumbuhan Inklusif}

Berdasarkan hasil analisis data yang telah dilakukan oleh peneliti diperoleh hasil bahwa kapasitas fiskal berpengaruh positif dan signifikan terhadap pertumbuhan inklusif di 34 provinsi yang ada di Indonesia tahun 2019. Koefisien variabel kapasitas fiskal daerah sebesar 0.001762 dengan probabilitas 0.9145 menjelaskan bahwa variabel tersebut tidak memiliki pengaruh yang signifikan terhadap pertumbuhan inklusif di Indonesia. 
Elastisitas fiskal mengukur elastisitas pendapatan asli daerah terhadap produk domestik bruto di daerah tersebut. Hasil perhitungan yang menunjukkan hasil elastis maka dapat diartikan bahwa daerah tersebut memiliki struktur PAD yang kuat. Sebagian besar provinsi di Indonesia sudah memiliki PAD yang elastis sehingga hal tersebut berpengaruh terhadap pertumbuhan inklusif di Indonesia. Daerah sudah mampu untuk mengelola PAD yang dimilikinya sehingga bisa memiliki struktur PAD yang kuat yang dapat digunakan untuk memenuhi kebutuhan masyarakat terutama dalam hal pemberian layanan publik untuk meningkatkan kesejahteraan masyarakat. Namun, hasil pengolahan data menunjukkan terdapat beberapa provinsi menghasilkan nilai inelastis. Hal tersebut memberikan arti bahwa pada saat terjadi perubahan Produk Domestik Regional Bruto (PDRB) maka hal tersebut tidak terlalu berpengaruh terhadap Pendapatan Asli Daerah. Terdapat daerah yang memiliki nilai inelastis justru memiliki nilai pertumbuhan inklusif yang tinggi seperti provinsi DKI Jakarta. Pada tahun 2018 memiliki nilai inelastis namun pertumbuhan inklusif di DKI Jakarta tinggi yaitu sebesar 7.65. Sehingga dapat dikatakan bahwa elastisitas tidak berpengaruh terhadap pertumbuhan inklusif dalam meningkatkan pertumbuhan ekonomi, mengurangi kemiskinan dan ketimpangan.

Hasil penelitian ini bertolak belakang dengan penelitian Nely Aulia (2014) yang memberikan hasil bahwa secara simultan elastisitas fiskal berpengaruh terhadap pertumbuhan ekonomi, tingkat kemiskinan dan kesenjangan pendapatan. Namun, penelitian ini sejalan dengan penelitian yang dilakukan oleh Utami \& Indrajaya (2019) memberikan kesimpulan bahwa pendapatan asli daerah dan belanja modal berpengaruh positif terhadap pertumbuhan ekonomi serta pendapatan asli daerah memiliki pengaruh yang signifikan terhadap kesejahteraan masyarakat melalui pertumbuhan ekonomi.

\subsubsection{Pengaruh Desentralisasi Fiskal, Kapasitas Fiskal Daerah dan Elastisitas Fiskal terhadap Pertumbuhan Inklusif Indonesia}

Beberapa penelitian terdahulu telah melakukan analisis secara parsial dari variabel independen diatas dengan berbagai hasil. Berdasarkan hasil analisis data yang telah dilakukan oleh peneliti memberikan hasil bahwa Uji F memiliki nilai kurang dari alpha 5\% sehingga derajat desentralisasi fiskal, kapasitas fiskal daerah, dan elastisitas fiskal secara bersama-sama berpengaruh signifikan terhadap pertumbuhan inklusif. Maka setiap penelitian atau kebijakan yang akan dilakukan terhadap pertumbuhan inklusif dapat menggunakan ketiga variabel tersebut sebagai pertimbangan.

Untuk meningkatkan pertumbuhan inklusif maka pemerintah diharapkan mampu meningkatkan desentralisasi fiskal dan kapasitas fiskal setiap daerah. Daerah harus lebih aktif dalam memanfaatkan transfer dana dari pemerintah pusat dan juga harus mampu menciptakan sumber pendapatan baru sesuai dengan potensi yang dimiliki oleh daerah untuk meningkatkan pendapatan asli daerahnya. Sehingga, dengan semakin tingginya pendapatan asli daerah yang tentunya harus dikelola dengan baik dapat memberikan manfaat yang besar yaitu meningkatkan pertumbuhan ekonomi yang disertai dengan semakin meningkatnya pula kesejahteraan masyarakat yang dilihat dari semakin menurunnya ketimpangan dan kemiskinan yang terjadi di daerah tersebut. Pada akhirnya setiap daerah akan bisa mencapai pertumbuhan inklusif yang memuaskan. 


\section{Simpulan}

Berdasarkan penelitian yang telah dilakukan, dapat disimpulkan bahwa: (1) Desentralisasi fiskal berpengaruh positif dan signifikan terhadap pertumbuhan inklusif Indonesia selama tahun 2017-2019 dengan nilai koefisien sebesar 2.653252. (2) Kapasitas fiskal daerah berpengaruh positif dan signifikan terhadap pertumbuhan inklusif Indonesia selama tahun 2017-2019 dengan nilai koefisien sebesar 0.375605. (3) Elastisitas fiskal berpengaruh positif dan tidak signifikan terhadap pertumbuhan inklusif Indonesia selama tahun 2017-2019 dengan nilai koefisien sebesar 0.001762. (4) Desentralisasi fiskal, kapasitas fiskal daerah dan elastisitas fiskal secara simultan berpengaruh signifikan terhadap pertumbuhan inklusif di Indonesia selama tahun 2017-2019.

\section{Daftar Rujukan}

Aulia, N. (2014). Hubungan Desentralisasi Fiskal Terhadap Pertumbuhan Ekonomi, Tingkat Kemiskinan, Dan Kesenjangan Pendapatan Kabupaten/Kota Di Provinsi Jawa Tengah Tahun 2012. Economics Development Analysis Journal, 3(2), 327-336. https://doi.org/10.15294/edaj.v3i2.3839

Basuki, A. T., \& Nano, P. (2016). Analisis Regresi dalam Penelitian Ekonomi \& Bisnis: Dilengkapi Aplikasi SPSS \& EVIEWS. PT Raja Grafindo Persada.

Hapsari, S. A. D., Hutagaol, M. P., \& Asmara, A. (2013). Pertumbuhan Inklusif : Fenomena Pertumbuhan Inklusif Di Kawasan Indonesia Bagian Barat Dan Indonesia Bagian Timur. Jurnal Ekonomi Dan Kebijakan Pembangunan, 2(2), 85-112. https://doi.org/10.29244/jekp.2.2.85-112

Gujarati, D. N. (2012). Dasar-dasar Ekonometrika, Terjemahan Mangunsong. RC (5th ed.). Jakarta: Salemba Empat.

Hastuti, P. (2018). Desentralisasi fiskal dan stabilitas politik dalam kerangka pelaksanaan otonomi daerah di indonesia. Simposium Nasional Keuangan $\quad$ Negara, https://jurnal.bppk.kemenkeu.go.id/snkn/article/view/293

Herdiyana, D. (2019). Analisis Data Peta Kapasitas Fiskal Daerah. Jurnal Pajak Dan Keuangan Negara, 1, 112133. https://doi.org/https://doi.org/10.31092/jurnal\%20pkn.v1i1.610

Hidayat, R. (2017). Political devolution: Lessons from a decentralized mode of government in Indonesia. SAGE Open, 7(1). https://doi.org/10.1177/2158244016686812

Islam, F. S. (2015). Pengaruh Desentralisasi Fiskal Terhadap Pertumbuhan Ekonomi, Kemiskinan, Penggangguran Dan Ketimpangan Perekonomian Kabupaten/Kota Di Jawa Tengah [Universitas Airlangga]. http://repository.unair.ac.id/id/eprint/3660

Juma'eh, Tiawon, H., \& Hukom, A. (2020). Analisis Kapasitas Fiskal dan Pengeluaran Pemerintah terhadap Pertumbuhan Ekonomi dan Kesejahteraan Masyarakat Provinsi Kalimantan Tengah. Journal of Environment and Management, 1(1), 40-45.

Klasen, S. (2010). Measuring and monitoring inclusive growth in developing and advanced economies: Multiple definitions, open questions and some constructive proposals. In Reframing Global Social Policy: Social Investment for Sustainable and Inclusive Growth (No. 12; Issue 12). https://doi.org/10.1332/policypress/9781447332497.003.0006

Kurniasih, D. E. (2020). Infrastructure and Inclusive Economic Growth in Decentralized Indonesia. Jurnal Ilmiah Administrasi Publik ( JIAP ), 6(1), 16-24.

Murad, A. (2019). DESENTRALISASI FISKAL DAN INKLUSIFITAS PERTUMBUHAN EKONOMI DIKABUPATEN/KOTA DI NTB. Jurnal Akuntansi dan Keuangan Syariah-ALIANSI, 3(2), 129-157.

Ramos, A., Raquel, Ranieri, R., Lammes, \& Jan-Willen. (2013). Mapping inclusive growth (No. 105). http://hdl.handle.net/10419/71778

Sitorus, A. V. Y., \& Arsani, A. M. (2018). A Comparative Study of Inter-Provincial Inclusive Economic Growth in Indonesia 2010-2015 with Approach Methods of ADB, WEF, and UNDP. Jurnal Perencanaan Pembangunan: The Indonesian Journal of Development Planning, 2(1), 64-77.

Tambunan, T. (2016). Pembangunan Ekonomi Inklusif: Sejauh Mana Indonesia? (I). LP3ES.

Todaro, M. P. (2000). Pembangunan Ekonomi di Dunia Ketiga (H. Munandar (ed.); Ketujuh). Erlangga. 
Jurnal Ekonomi, Bisnis dan Pendidikan, 1(2), 2021, 120-134

Utami, D. N., \& Indrajaya, I. G. B. (2019). Pengaruh Pad Dan Belanja Modal Terhadap Pertumbuhan Ekonomi Dan Kesejahteraan Masyarakat Di Provinsi Bali. E-Jurnal EP Unud, 8(10), 2195-2225.

Zhuang, J. (2010). Poverty, Inequality, and Inclusive Growth in Asia: Measurement, Policy Issues, and Country Studies (English). Asian Development Bank. https://doi.org/https://doi.org/10.7135/UP09780857288066.003

Zulyanto, A. (2012). Pengaruh Desentralisasi Fiskal terhadap Pertumbuhan Ekonomi di Provinsi Bengkulu. Ecosains: Jurnal Ilmiah Ekonomi Dan Pembangunan, 1(1). http://ejournal.unp.ac.id/index.php/ekosains/article/view/3465

Makmara, T. (2010). Tuturan Persuasif Wiraniaga dalam Berbahasa Indonesia: Kajian Etnografi Komunikasi. (Disertasi). DISERTASI dan TESIS Program Pascasarjana UM. 